\title{
重複波堤前面に消波工を設置した場合の波力
}

\author{
赤塚 雄 三*.竹田英 章**.蓮 見 隆***
}

\section{1. 消波工の必要性と実験の目的}

本来，防波堤は港内岂静穏に保つために設けられる港 湾構造物であり，既設の防波堤は波浪に対する遮蔽効果 を念頭に执いて設計されたものが大部分である。しかし ながら，近年，防波堤の配置によっては，生ずるところ の反射波による港口部の擾乱とか，防波堤外側における 養殖漁業の操業におよぼす悪影響が問題となって, 反射 波を軽減することを目的として，防波堤港外側前面に消 波工の設置を求められる事例が次第に増加している。こ の傾向は重複波堤として設計された防波堤についても同 様である。しかしながら，重複波堤前面に消波工として の異型ブロックを設置する場合，これが砕波の誘因とな って, 防波堤堤体に作用する波力が増大し, 堤体の拡幅 が必要となることが影念される。

すなわち, 重複波としての波力は, サンフル一公式に よって求めた場合，伊藤ら に式（1）で表わされるといわれている。

$P=0.8 \sim 1.0 W_{0} H$

ここに, $P$ : 波圧強度, $W_{0}$ ：水の単位体積重量,

$H$ : 波高

一方，防波堤の前面に消波工を設置した場合の平均波 压強度は， $P=1.0 W_{0} H$ で求められ, 重複波としての波 力より多少，上まわる值となっている。この場合の波压
は，砕波する波を堤前で砕くことにより，波力を減ずる 目的で消波工を設けた場合のものである。多少異なった 性質のものであるかもし秃ないが，重複波堤の前面に反 射波を軽隇するために異型ブロックを設置すれば，在来 の設計手法による限りでは，波力が増大する結果，既設 の堤体断面では不安定となり，堤体の拡幅を余儀なくさ れる事例も出てくる。

しかし，消波工を設置する上に，既設の堤体を拡幅す ることは，多額の経費を要するだけでなく，港内側の航 路とか，泊地の配置によっては拡幅が物理的に困難な場 合も少なくない。また，反射波を軽減する形式の重複波 堤を新たに設計する場合についても，同様のことがいえ る。そこで, 本実験では重複波堤としての堤体前面に作 用する波力と堤体前面に消波工を設置した場合の波力を 測定し，両者を比較することにより，重複波堤前面に反 射波を軽減するために消波工を設置した場合の設計法に 関する基礎的な資料を提出することを目的として実施し たものである。

\section{2. 堤体滑動抵抗力の測定方法}

\section{（1）実 験 施 設}

実験に使用した水路は，図一1 に示すようなフラップ 式造波装置有する造波水路である。この造波水路の諸 元は, 長さ $30 \mathrm{~m}$, 幅 $0.5 \mathrm{~m}$, 深さ $1.5 \mathrm{~m}$ で, 水路内での 最大発生波高は $40 \mathrm{~cm}$ ，発生波の周期は $1.0 \mathrm{sec〜} 4.0 \mathrm{sec}$

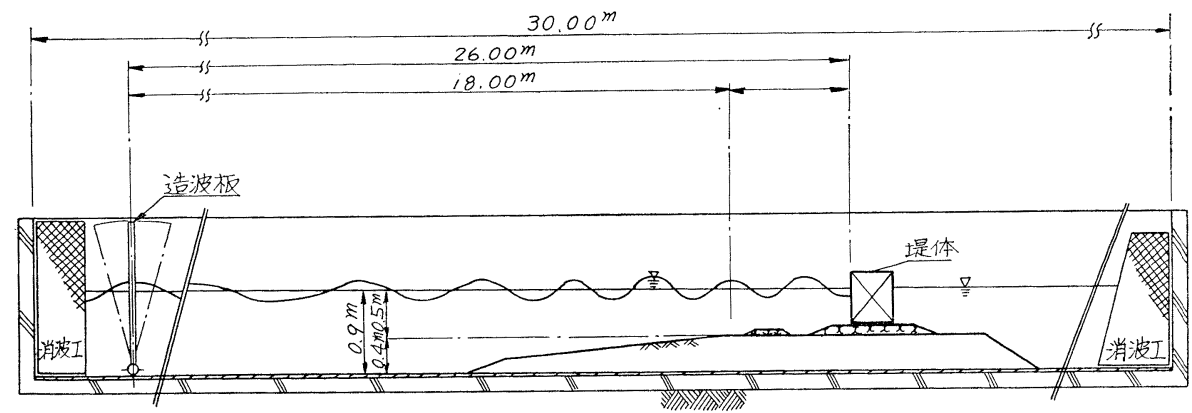

図一1 実 験 水 路 
表一1 実験波の諸元

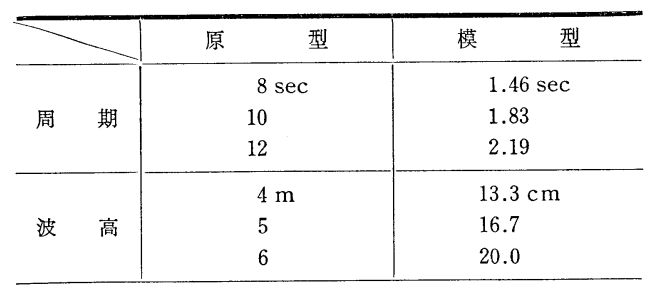

である。波高計としては，容量式波高計を用いた。

\section{（2）模型縮尺および実験諸元}

模型縮尺は，鉛直・水平ともに $1 / 30$ とし，それぞれ， フルードの相似則に従うものとして実験結果を整理し た。実験水位は $\pm 0.0 \mathrm{~m}$ とし, 実験波として 表一 1 に 示すような波高および周期を用いて行った。

\section{(3) 模型断面}

模型の断面は 図一 2 に示すように，水深一 $50 \mathrm{~cm}$ （原 型 $-15.0 \mathrm{~m}$ ) （注：以下かっこ内は原型寸法）の海底面 上に, $10 \mathrm{~cm}(3.0 \mathrm{~m})$ 厚の直径 $3 \sim 5 \mathrm{~cm}$ の石を並べたマ ウンドを設置し，その上に幅 $50 \mathrm{~cm}(15.0 \mathrm{~m})$, 高さ $60 \mathrm{~cm}(18.0 \mathrm{~m})$ の堤体を設置した。堤体はモルタル製の 中空箱で，中に鉛の重りを入れて重量を変化さすことが 出来る水密性の箱 (高さ $60 \mathrm{~cm} \times$ 幅 $50 \mathrm{~cm} \times$ 長さ $38 \mathrm{~cm}$ ) である。この堤体の前面に原型で 16 トンの異型ブロッ クを堤体の天端高 $+20 \mathrm{~cm}(+6.0 \mathrm{~m})$ と同一の高さまで 積み上げ，天端幅 $14.4 \mathrm{~cm}(4.3 \mathrm{~m})$ を確保しのり勾配を 1:1.33で海底にすりつけた断面とした。

\section{（4）実験方法}

波力の測定方法としては, 伊藤らの提案による式 (2) を用い，堤体の重量を連続的に変化させ，ある波力を受 けた場合，堤体が滑動しはじめる限界の重量を求め，市 らかじめ測定ずみの堤体底面とマウンド石面との静止摩 擦係数 $\mu$ を用いて堤体に作用する波力を算定した。

$$
\boldsymbol{P}=\mu(W-U)
$$

ここに, $\boldsymbol{P}$ : 波力, $\mu$ : 摩擦係数, $W$ : 堤体重量,

$U$ : 浮力または揚圧力

摩擦係数は水中に設置したばねばかりで堤体の底部を
引張り, 50 回の平均值から求めた。その結果は $\mu=0.62$ で，その標準偏差は 0.020 であった。港湾構造物の設計 には, 従来よりコンクリートと捨石の摩擦係数として, $\mu=0.60$ を用いているが実験值はこれとよく一致してい るので, 実験の整理に用いる摩擦係数としては実験值の 0.62 を用いた。

波力の測定に用いた実験対象波は, 本実験装置と実験 波の諸元によって求めた有効測定時間および波形記録か ら波の最も安定する第 7 波から第 11 波の 5 波を実験対 象波とした。

堤体の滑動現象は目測で判定した。すなわち, 水路に 基準点を設け, 堤体には $1 \mathrm{~mm}$ 刻みの物指を張りつけ て, 実験波 5 波に対して $2.5 \mathrm{~mm}$ 以上の移動 $(=0.5 \mathrm{~mm}$ /波）をって滑動と判定した。その上, 同一重量で 3 回実験を繰返して滑動限界重量を確認した。堤体の滑動 限界值は，相当のばらつきが予想されたので，予測した 波力に比し, 極端に重い重量から測定を始め, 順次軽量 化し滑動の開始した堤体重量からさらに数 $\mathrm{cm}$ の堤体 移動の認められた堤体重量までの，それぞれについて連 続的に測定し，たとえば，図一-3のように堤体の移動量 と重量の関係を図上にプロットして堤体の滑動限界重量 を求めた。

\section{3. 重複波堤に作用する波力}

重複波堤に作用する波力の実験結果を表一 2 に示す。

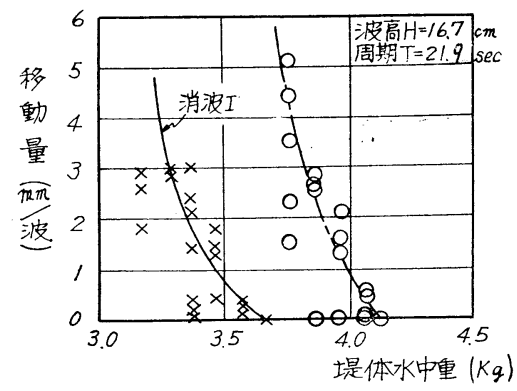

図一3堤体滑動限界の判定に用いた堤体重量と 移動量との関係（○消波工なし，×消波 エ西り)

模型樎尺 $1: 30$

現地寸法，单位： $m$

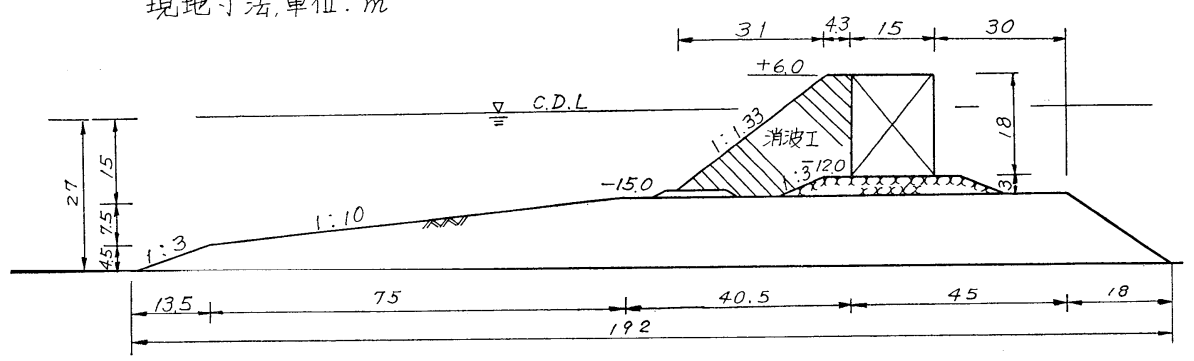

図一2 模型断 面 
同表には，伊藤式（3）および合田式2（4）を用いて 求めた波力と，それぞれの静水面上での波圧強度，およ び平均波圧係数を示した。

$$
\boldsymbol{P}=P l=\mu\left(W-P \frac{B}{2}\right)
$$

ここに，B: 堤体幅，本実験では $B=50 \mathrm{~cm}$

$$
\boldsymbol{P}=\mu(W-U)
$$

$$
\text { ここに, }
$$

$$
U=1 / 2 \quad P_{u} B
$$$$
P_{u}=\alpha_{1} \alpha_{3} W_{0} H
$$$$
\alpha_{1}=0.6+\frac{1}{2}\left[\frac{4 \pi h / L}{\sinh (4 \pi h / L)}\right]^{2}
$$$$
\alpha_{3}=1-\frac{h^{\prime}}{h}\left[1-\frac{1}{\cosh (2 \pi h / L)}\right]
$$

$h^{\prime}$ ：防波堤直立部底面から静水面までの高さ

$h:$ 防波堤の設置水深

$L$ : 波長

表一2 によれば，合田式より求めた平均波圧係数は， 伊藤式によるものよりやや大きめであるが，その範囲は どちらも $0.4 \sim 0.7$ の範囲となっている。

\section{4. 重複波堤に消波工を設置した場合の波力}

重複波堤前面に消波工を設けた場合の堤体に作用する 波力は，表一3 に示すと抢りである。同表には前節にお
けると同様に伊藤式と合田式を用いて求めた波力，波圧 強度および平均波圧係数を示した。これによると伊藤式 をもとにして求めた平均波圧係数は $0.34 \sim 0.52$ の範囲 にあり，合田式をもとにして求めた平均波圧係数 0.30 0.57 とほぼ同様で，0.3〜0.6 の範囲にある。

\section{5. 重複波領域における波力減殺効果}

表一4 は，重複波堤に作用する波力と重複波堤に消波 工を設けた場合の波力との比を波高と周期ごとに対比し て整理したもので，さらに，波力比と波形勾配との関係 を示したものが図一4である。これによると, 重複波 堤においても消波工を設置した場合の波力は，設置しな い場合に比して，8～26\% 減少している。また消波工の

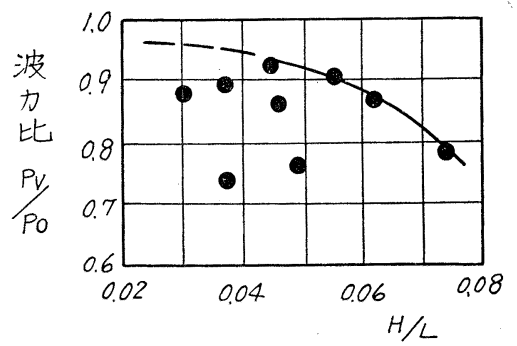

図一4 消波工の有無による波力比と波形勾配

\begin{tabular}{|c|c|c|c|c|c|c|c|c|c|c|c|c|}
\hline \multirow{3}{*}{$\begin{array}{l}\text { 奏験 } \\
\text { 番号 }\end{array}$} & \multicolumn{2}{|c|}{ 波 } & \multicolumn{2}{|c|}{ 浪 } & \multicolumn{2}{|c|}{ 堤体水中重量 } & \multirow{3}{*}{$\begin{array}{c}\text { 波 } \\
\text { 伊藤 式 } \\
(\mathrm{g} / \mathrm{cm})\end{array}$} & \multirow{3}{*}{ 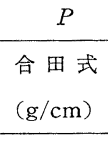 } & \multirow{3}{*}{$\begin{array}{c}\text { 波 圧 } \\
\text { 伊藤 式 } \\
P\left(\mathrm{~g} / \mathrm{cm}^{2}\right)\end{array}$} & \multirow{3}{*}{\begin{tabular}{|c|} 
合望 \\
\\
$P_{1}\left(\mathrm{~g} / \mathrm{cm}^{2}\right)$
\end{tabular}} & \multicolumn{2}{|c|}{ 平均波王係 数 } \\
\hline & \multicolumn{2}{|c|}{ 波 高 $H$} & \multicolumn{2}{|c|}{ 周 期 $T$} & \multirow{2}{*}{$\begin{array}{r}W \\
(\mathrm{~kg})\end{array}$} & \multirow{2}{*}{$\begin{array}{c}W^{\prime} \\
(\mathrm{g} / \mathrm{cm}) \\
\end{array}$} & & & & & 伊 藤 式 & 合田式 \\
\hline & $\begin{array}{c}\text { 原 型 } \\
(\mathrm{m})\end{array}$ & $\begin{array}{l}\text { 横 型 } \\
(\mathrm{cm})\end{array}$ & $\begin{array}{l}\text { 原 型 } \\
(\mathrm{sec})\end{array}$ & $\begin{array}{l}\text { 模 型 } \\
(\mathrm{sec})\end{array}$ & & & & & & & $P / W_{0} H$ & $P / W_{0} H$ \\
\hline 1 & 4.0 & 13.3 & 8.0 & 1.46 & 30.2 & 794 & 387 & 396 & 6.83 & 7.69 & 0.51 & 0.52 \\
\hline 2 & 4.0 & 13.3 & 10.0 & 1.83 & 36.6 & 963 & 469 & 525 & 8.28 & 11.48 & 0.62 & 0.70 \\
\hline 3 & 4.0 & 13.3 & 12.0 & 2.19 & 34.6 & 911 & 443 & 499 & 7.83 & 11.33 & 0.59 & 0.66 \\
\hline 4 & 5.0 & 16.7 & 8.0 & 1.46 & 37.7 & 992 & 489 & 493 & 8.15 & 9.22 & 0.49 & 0.49 \\
\hline 5 & 5.0 & 16.7 & 10.0 & 1.83 & 43.7 & 1150 & 566 & 602 & 9.44 & 13.03 & 0.57 & 0.62 \\
\hline 6 & 5.0 & 16.7 & 12.0 & 2.19 & 41.1 & 1082 & 533 & 588 & 8.88 & 12.78 & 0.69 & 0.59 \\
\hline 7 & 6.0 & 20.0 & 8.0 & 1.46 & 39.7 & 1045 & 515 & 502 & 8.58 & 9.21 & 0.43 & 0.42 \\
\hline 8 & 6.0 & 20.0 & 10.0 & 1.83 & 48.0 & 1263 & 622 & 675 & 10.37 & 13.84 & 0.52 & 0.56 \\
\hline 9 & 6.0 & 20.0 & 12.0 & 2.19 & 49.7 & 1308 & 644 & 712 & 10.74 & 15.14 & 0.54 & 0.59 \\
\hline
\end{tabular}
$P_{v}$ : 消波工ある場合の波力, $P_{0}$ : 消波 工ない場合の波力

\begin{tabular}{|c|c|c|c|c|c|c|c|c|c|c|c|c|}
\hline \multirow{3}{*}{$\begin{array}{l}\text { 実験 } \\
\text { 番号 }\end{array}$} & \multicolumn{2}{|c|}{ 波 } & \multicolumn{2}{|c|}{ 浪 } & \multicolumn{2}{|c|}{ 堤体水中重量 } & \multicolumn{2}{|c|}{ 波 力 } & \multicolumn{2}{|c|}{ 波 圧 強 度 } & \multicolumn{2}{|c|}{ 平均波王係数 } \\
\hline & \multicolumn{2}{|c|}{ 波 高 $H$} & \multicolumn{2}{|c|}{ 周 期 $T$} & \multirow{2}{*}{$\begin{array}{c}W \\
(\mathrm{~kg})\end{array}$} & \multirow{2}{*}{$\begin{array}{c}W^{\prime} \\
(\mathrm{g} / \mathrm{cm})\end{array}$} & \multirow{2}{*}{$\begin{array}{c}\text { 伊 藤 式 } \\
(\mathrm{g} / \mathrm{cm})\end{array}$} & \multirow{2}{*}{$\begin{array}{l}\text { 合 田 式 } \\
(\mathrm{g} / \mathrm{cm})\end{array}$} & \multirow{2}{*}{$\left|\begin{array}{c}\text { 伊 藤 式 } \\
P\left(\mathrm{~g} / \mathrm{cm}^{2}\right)\end{array}\right|$} & \multirow{2}{*}{$\begin{array}{l}\text { 合 田 式 } \\
P_{1}\left(\mathrm{~g} / \mathrm{cm}^{2}\right)\end{array}$} & \multirow{2}{*}{$\begin{array}{c}\text { 伊 藤 式 } \\
P / W_{0} H\end{array}$} & \multirow{2}{*}{$\begin{array}{l}\text { 合田 式 } \\
P / W_{0} H\end{array}$} \\
\hline & $\begin{array}{c}\text { 原 型 } \\
(\mathrm{m})\end{array}$ & $\begin{array}{l}\text { 模 型 } \\
(\mathrm{cm})\end{array}$ & $\begin{array}{l}\text { 原 型 } \\
(\mathrm{sec})\end{array}$ & $\begin{array}{l}\text { 模 型 } \\
(\mathrm{sec})\end{array}$ & & & & & & & & \\
\hline 1 & 4.0 & 13.3 & 8.0 & 1.46 & 22.9 & 603 & 293 & 277 & 5.18 & 5.37 & 0.39 & 0.37 \\
\hline 2 & 4.0 & 13.3 & 10.0 & 1.83 & 26.9 & 708 & 345 & 367 & 6.09 & 8.02 & 0.46 & 0.49 \\
\hline 3 & 4.0 & 13.3 & 12.0 & 2.19 & 30.3 & 797 & 388 & 424 & 6.86 & 9.74 & 0.52 & 0.57 \\
\hline 4 & 5.0 & 16.7 & 8.0 & 1.46 & 32.7 & 861 & 424 & 412 & 7.07 & 7.70 & 0.42 & 0.41 \\
\hline 5 & 5.0 & 16.7 & 10.0 & 1.83 & 37.6 & 989 & 488 & 523 & 8.13 & 10.95 & 0.49 & 0.52 \\
\hline 6 & 5.0 & 16.7 & 12.0 & 2.19 & 36.6 & 963 & 475 & 514 & 7.91 & 11.18 & 0.47 & 0.51 \\
\hline 7 & 6.0 & 20.0 & 8.0 & 1.46 & 31.2 & 821 & 404 & 363 & 6.74 & 8.67 & 0.34 & 0.30 \\
\hline 8 & 6.0 & 20.0 & 10.0 & 1.83 & 43.4 & 1142 & 563 & 600 & 9.83 & 12.30 & 0.47 & 0.50 \\
\hline 9 & 6.0 & 20.0 & 12.0 & 2.19 & 45.6 & 1200 & 591 & 645 & 9.85 & 13.72 & 0.49 & 0.54 \\
\hline
\end{tabular}

表一2 重複波堤に作用する波力

表一3 重複波堤に消波工を設置した場合の波力 
有無による波力の差は，波形勾配が小さくなるにしたが い，すなわち波高が同一であれば周期が長いほど，減少 する傾向が認められる。

表一4 消波工の有無による波力比

\begin{tabular}{|c|c|c|c|c|c|c|}
\hline \multirow{2}{*}{$\begin{array}{l}\text { 実験 } \\
\text { 番号 }\end{array}$} & \multirow{2}{*}{$\frac{\text { 波 }}{\text { 波高 }(\mathrm{m}) \mid}$} & \multirow{2}{*}{ 浪 } & \multicolumn{2}{|c|}{ 消波工有無の波力 } & \multirow{2}{*}{$\begin{array}{c}\text { 波力比 } \\
P_{v} / P_{0}\end{array}$} & \multirow{2}{*}{$\begin{array}{c}\text { 水深波高比 } \\
d / H\end{array}$} \\
\hline & & & $\begin{array}{l}P_{0}: \text { なし } \\
(\mathrm{g} / \mathrm{cm})\end{array}$ & $\begin{array}{l}P_{v}: \text { あり } \\
(\mathrm{g} / \mathrm{cm})\end{array}$ & & \\
\hline 1 & 4.0 & 8.0 & 387 & 293 & 0.76 & 3.0 \\
\hline 2 & 4.0 & 10.0 & 469 & 345 & 0.74 & 3.0 \\
\hline 3 & 4.0 & 12.0 & 443 & 388 & 0.88 & 3.0 \\
\hline 4 & 5.0 & 8.0 & 489 & 424 & 0.87 & 2.4 \\
\hline 5 & 5.0 & 10.0 & 566 & 488 & 0.86 & 2.4 \\
\hline 6 & 5.0 & 12.0 & 533 & 475 & 0.89 & 2.4 \\
\hline 7 & 6.0 & 8.0 & 515 & 404 & 0.79 & 2.0 \\
\hline 8 & 6.0 & 10.0 & 622 & 563 & 0.90 & 2.0 \\
\hline 9 & 6.0 & 12.0 & 644 & 591 & 0.92 & 2.0 \\
\hline
\end{tabular}

図一5 法, 波力係数と水深・波高比 $d / H$ の関係につ いて, 著者らの実験結果を伊藤 ${ }^{11}$, 堀川ら ${ }^{3)}$ の実験結果 および 48 年度に当事務所に扔いて行った実験結果とあ わせて示したものである。これによると， $d / H=0 \sim 2.0$,

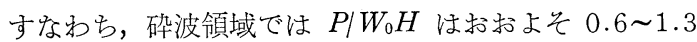
の範囲にあるが，重複波領域では，0.4 0.7 付近に分 布して确波領域とも比較的よい連続性を示す。また， $d / H$ が負になる領域，すなわち，マウンドあるいは，消 波工の天端が静水面上にある場合，その天端高が来襲波 高と同一高さ以上であれば，波力係数は 0.5 以下で相当 の消波効果が得られ，重複波堤として在来の設計方法に よって設計しても危険はない。しかし，消波工や捨石マ ウンドの天端が来襲波高の $1 / 2$ 以下あるいは静水面付近 にある場合には，乙れが砕波の誘因となり，波力係数 $P / W_{0} H$ は 0.7 をはるかに越えて 1.0 以上となり, 設計 で考慮した以上の波力が作用する可能性を示している。 この点は, 設計だけでなく施工にさいしても, 十分に注 意すべきことであろう。

\section{6. 結 論}

本調査は重複波堤の前面に，反射波安軽隇する目的で 消波工を設置した場合に，堤体に作用する波力定案験的 に検討し，その設計法に関する基礎資料を提出すること を目的として実施したもので，本実験の範囲内で次のこ とがいい得ると思わ秃る。

（1）重複波堤前面に消波工を設置することにより， 堤体に作用する波力は，消波工を設置しない重複波堤に 作用する波力より，打抢よそ 10\% 20\% 減少する。

（2）重複波堤に作用する平均波圧強度は，0.4 0.7 $W_{0} H$ であるのに対して，消波工を設けた場合の平均波 圧強度は，0.3 0.6 $W_{0} H$ 程度である。

（3）消波工の有無による波力の差は，波形勾配によ って変化し，波形勾配が小さくなるにしたがって両者の 差は減少する傾向を示している。

（4）本実験結果とともに, 伊藤, 堀川らの実験結果 を整理して, 水深・波高比々平均波圧係数の関係を求め ると重複波領域から砕波領域まで比較的良好な連続性を 示す。また重複波堤前面の消波効果が消波工の設置高さ によって著しく変化しており, 波力の減少効果安期待す るためには，消波工の高さを $0.6 H$ 以上にすべきこと が確かめられた。

\section{7. あとがき}

限られた条件の下ではあったが，重複波堤前面に反射 波它軽減する目的で異型ブロック它設置する場合の波力 について実験的に検討した。その結果，異型ブロックを 堤体と同程度の高さまで積み上げた場合についての波力 は, 減少していることが判明し, 在来の手法により重複 波堤として設計しても安全側にあることがわかった。

今後は現地観測や施工例を通じて確認する予定であ る。また，同様の機能をもつ直立消波工を有する単塊構

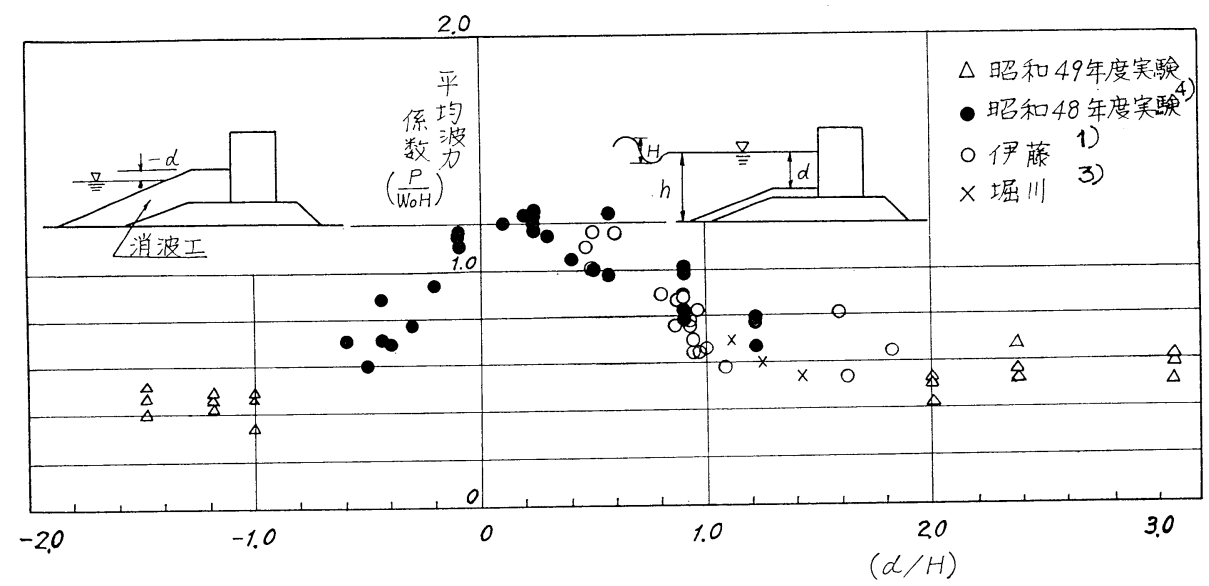

図一5 平均波力係数と水深波高比の関係 
造の重複波堤に対する適用性についても，今後検討する 必要吕あうう。

最後に本実験を行うにあたり，種々の助言をいただい た港湾技術研究所, 波浪研究室の合田室長ならびに, 同 防波堤研究室の谷本室長に深く感謝します。なお, 水路 実験は日本港湾コンサルタントに委託して行った。

\section{引用 文 献}

1）伊藤喜行・藤島 睦・北谷高雄：防波堤の安定性
に関する研究，港湾技術研究所報告，第 5 巻 41 号, 1966 年.

2）合田良実：防波堤の設計波圧に関する研究，港湾 技術研究所報告, 第 12 巻 3 号, 1973 年.

3）堀川清司 - 小沢保臣・高橋邦夫：高基混成堤直立 部の期待滑動量について, 第 19 回海岸工学講演 会論文集，1972 年.

4) 運輸省第二港湾建設局横浜調査設計事務所:（横 調資料第 127 号), (小名浜港二次元断面実験報告 書), 昭和 49 年 3 月. 